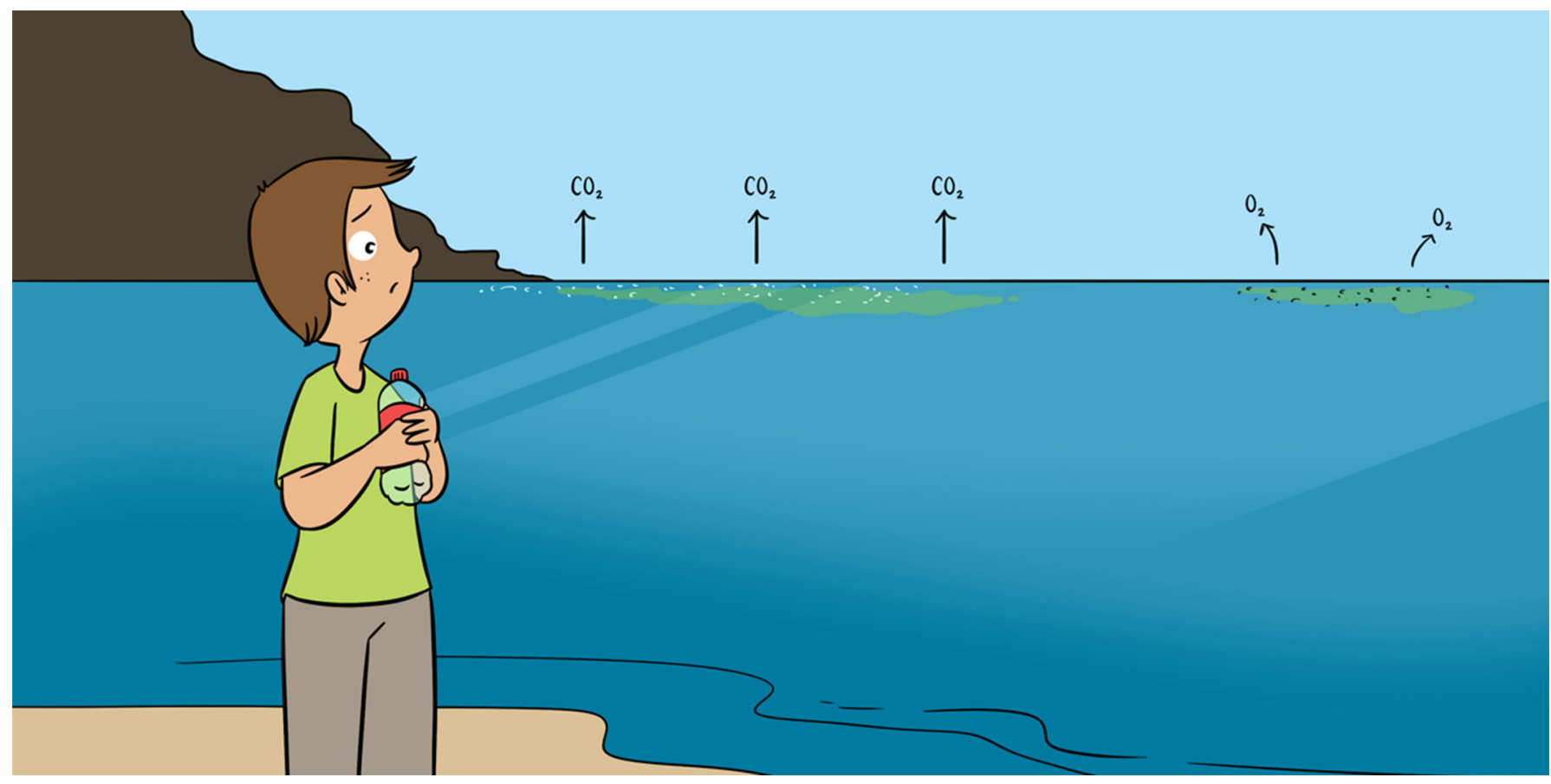

\title{
HOW CAN PLASTIC ON THE SEA SURFACE AFFECT OUR CLIMATE?
}

\author{
Luisa Galgani ${ }^{1,2^{*}}$ and Steven A. Loiselle ${ }^{1,2}$ \\ ${ }^{1}$ Department of Biotechnology, Chemistry and Pharmacy, University of Siena, Siena, Italy \\ ${ }^{2}$ CSGI - Center for Colloids and Surface Science, Sesto Fiorentino, Italy
}

YOUNG REVIEWER:

SAMUEL

AGE: 12
Plastic particles from packaging, personal care products, synthetic clothing, and many other applications, are a potential risk to the ocean's health. Tiny, light particles of plastic can float on the sea surface for a long time. The sea surface is a special place: it is rich in chemical compounds produced by marine organisms below. Sometimes these substances make the sea surface appear as a shining, darker or brighter layer. The sea surface also connects the ocean and the atmosphere and controls important exchanges between those two systems, including the flow of oxygen, which is an essential element for life, and the flow of carbon dioxide, one of the main gases responsible for climate change. Plastic particles can increase the amount of chemical compounds in the sea surface layer, because marine microorganisms (like bacteria) may be more productive in the presence of plastic particles than they are in plastic-free environments. This increased production and bacterial activity can reduce the oxygen content of the water. We did a simple experiment to explore this mechanism. 
PHYTOPLANKTON

Microscopic marine algae that serve as food for a wide range of sea creatures including whales, shrimp, snails, and jellyfish.

PHOTOSYNTHESIS

A process used by plants, also marine plants, and other organisms to convert light energy into chemical energy producing food for the organism to survive. Photosynthesis needs carbon dioxide $\left(\mathrm{CO}_{2}\right)$, water and light to take place. Through light energy, the process of photosynthesis converts $\mathrm{CO}_{2}$ and water in carbohydrates and oxygen.

\section{CARBOHYDRATES}

Biomolecules

consisting of carbon

(C), hydrogen $(\mathrm{H})$, and oxygen (O) atoms. The term can be a synonym of saccharides, a group that includes sugars, starch, and cellulose.

BIOGEOCHEMICAL CYCLE

A pathway that a chemical substance, like carbon, moves through. These cycles include stages in which the substance is present in living things and other stages where it is present in non-living things. The carbon cycle is an especially important biogeochemical cycle.

ORGANIC MATTER

Carbon-based compounds found in natural environments. Organic matter comes from plants and animals and their waste products.

\section{THE SURFACE OF THE OCEAN}

On a calm day by the sea, if you look at the water from a distance you may observe a glassy, shining surface. Sometimes it looks like there is a film of oil on top of the water. These spots may appear darker or brighter compared to the water around them. When there are few waves, when the sun is shining, and when there is not much wind, the surface of the sea may appear like a smooth, reflective mirror.

The ocean has different zones, and the surface layer has special properties that make it different from the water just a few centimeters below. But the ocean holds a massive volume of water, from the surface down to the abyss. Why should such a thin surface layer be interesting, if it only represents a small volume of the whole ocean? Here is why this thin layer is so important. The ocean covers almost $70 \%$ of the Earth's surface. This means that $70 \%$ of the Earth's surface is the ocean's surface [1]. The ocean's surface is in an important position, because it connects two systems: the water and the air. Since it is in the middle, the sea surface mediates all exchanges between the ocean and the atmosphere. We think that the sea surface layer may also be very important for the world's climate. To understand why, let us step back and look at the circle of life in the ocean.

\section{MICRO-LIFE IN THE OCEAN: THE CARBON CYCLE}

Phytoplankton and bacteria are small marine organisms that support all life in the ocean. With only sunlight and carbon dioxide $\left(\mathrm{CO}_{2}\right)$, phytoplankton can produce sugars. This process is called photosynthesis. Sugars contain carbon and hydrogen atoms and are therefore called carbohydrates. Carbohydrates are the building blocks of living things. Phytoplankton also produce oxygen (Figure 1). About $70 \%$ of the oxygen that we breathe comes from these tiny, plant-like creatures in the ocean. Bacteria consume and transform the carbohydrates and oxygen generated by phytoplankton. In this process, the bacteria put $\mathrm{CO}_{2}$ back into the water, the sea surface and finally, the atmosphere.

From tiny microbes to large whales, all forms of marine life rely on this cycle, which is known as the biogeochemical cycle of carbon. In perfect conditions, the production and consumption of oxygen and $\mathrm{CO}_{2}$ are in balance. Phytoplankton and bacteria produce and transform "good" chemical compounds made with carbon, called organic matter. This organic matter accumulates in high concentrations at the sea surface, where it serves as food for other bacteria. Bacteria can live and prosper at the sea surface when there are high concentrations of organic matter. The more organic matter, the more active the bacteria. As a result, more oxygen is consumed and more $\mathrm{CO}_{2}$ released at the air-sea interface [2] 
Figure 1

The biogeochemical carbon cycle in the ocean. Carbon moves between living things and non-living things From the atmosphere, in the form of $\mathrm{CO}_{2}$, carbon is absorbed by phytoplankton and incorporated into glucose (sugar, a carbohydrate) in the process of photosynthesis, which contemporarily produces oxygen. Through photosynthesis, these marine creatures can produce up to $70 \%$ of the oxygen that we breathe. In seawater, bacteria consume carbohydrates to get energy. In this process bacteria respire, using oxygen and releasing $\mathrm{CO}_{2}$. They also transform carbohydrates into other compounds (organic matter). This way carbon now travels through the bacteria into organic matter and then back to $\mathrm{CO}_{2}$ as it moves again to the atmosphere.

\section{MICROPLASTICS}

Small pieces of plastic $<5 \mathrm{~mm}$ in length.

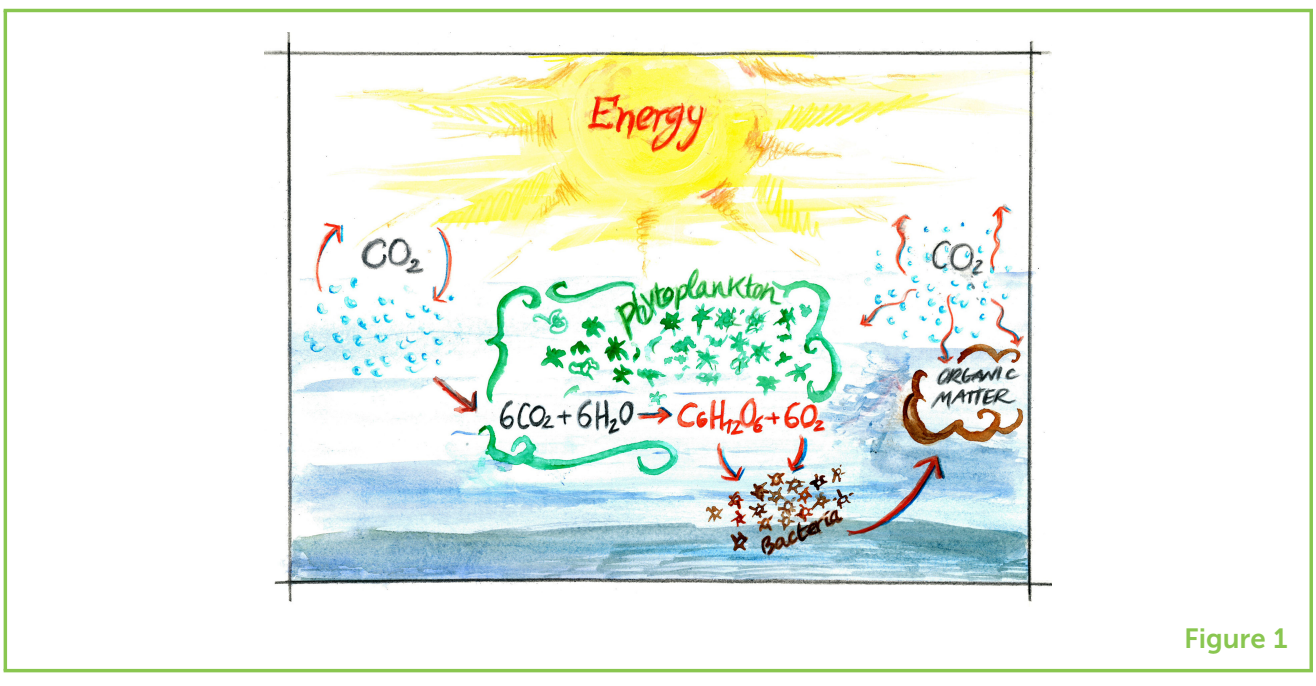

\section{PLASTIC ON THE SEA SURFACE}

Unfortunately, there are "bad" materials on the sea surface, too. Most originate from man-made pollution, and one of the most common is plastic. Plastics play a fundamental part in our everyday lives. However, many of the single-use plastics we use, like plastic bags, takeaway cups and lids, plastic straws, end up in the sea, where they do not belong. Plastics were already floating in the ocean almost 50 years ago [3]. The plastics found on the sea surface are usually light, small particles $(<5 \mathrm{~mm})$ called microplastics, which can float in this marine compartment for a long time. Most microplastics come from the fragmentation of bigger objects through the action of sun, waves, and even munching by marine animals. Microplastic fibers get to the ocean through the water discharged by domestic washing machines when loaded with synthetic clothes. Some plastics may be accidentally discharged or lost at sea, like fishing nets. However, more than $80 \%$ of the plastic in the ocean comes from land: rivers, households, and mismanaged waste.

Let us imagine what happens at the sea surface: we have a lot of organic matter and many active bacteria transforming it and producing $\mathrm{CO}_{2}$. Then comes the plastic. Since bacteria cannot swim but are carried by the currents, any particle big enough for the bacteria to attach to will provide a place for them to live. The more places to attach, the more bacteria will end up living in that environment. More bacteria means that more oxygen will be used and more $\mathrm{CO}_{2}$ will be produced (Figure 2). 
Figure 2

Small plastics particles $(<5 \mathrm{~mm})$ can float on the sea surface for long time. When bacteria encounter these particles on the sea surface, they can produce organic matter and transform pre-existing compounds that help them sticking to the particles, producing $\mathrm{CO}_{2}$. This way, the organic matter produced and accumulated at the sea surface can slow down the flux of oxygen and $\mathrm{CO}_{2}$ between the ocean and the atmosphere. MPs, microplastics.

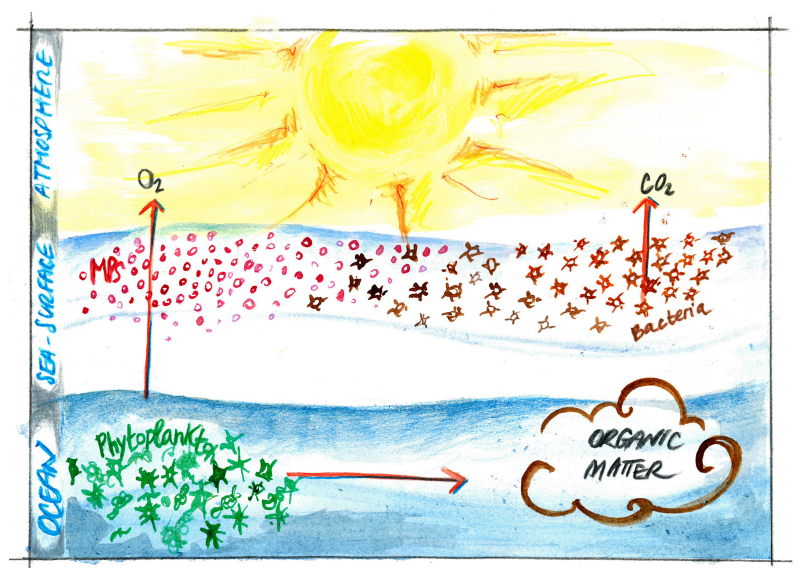

Figure 2

\section{BACTERIA PRODUCE MORE ORGANIC MATTER AND USE MORE OXYGEN WHEN PLASTIC IS PRESENT}

The sea surface is complicated to study. So to study the bacterial response to microplastics, we recreated a simplified sea in our lab. We made our own seawater and then added a "soup" of organic matter and bacteria. Then we studied the bacteria in the presence and absence of plastic [4]. We used two small tanks, each containing $4.5 \mathrm{~L}$ of artificial seawater. One tank, called the control, was free of microplastics. We added about 1,300 particles of microplastic per liter to the other tank, called the treatment (Figure 3). We took samples from the water surface and the water below the surface during a 24-h period. In each sample, we measured oxygen, organic matter, and the number of bacteria. We compared the measurements between the control and the treatment.

We observed that there was more organic matter present in the samples that came from the tank containing microplastics, and this difference was even greater in the samples taken from the water surface. When organic matter accumulates at the water surface, it can impede the flow of oxygen to the water below. We saw this in our experiment: the more organic matter was present, the lower the oxygen concentration right below the surface water (Figure 4). So, we can conclude that, when microplastics are present, bacteria produce more organic matter. In our experiment, the bacteria must have transformed the organic matter that we added to the tank and produced new organic compounds. This process uses up oxygen.

The number of bacteria did not change throughout the experiment. This was a surprise. But we have an explanation: we could only measure free-floating bacteria. There might have been billions of bacteria stuck to the microplastic particles that we could not 
Figure 3

Experimental setup. In the control, only bacteria and organic matter were present. In the treatment, plastic particles were also present. During the 24-h experiment, we collected samples of the surface water and of the water below the surface. The amounts of organic matter, bacteria, and oxygen were measured in each of the samples.

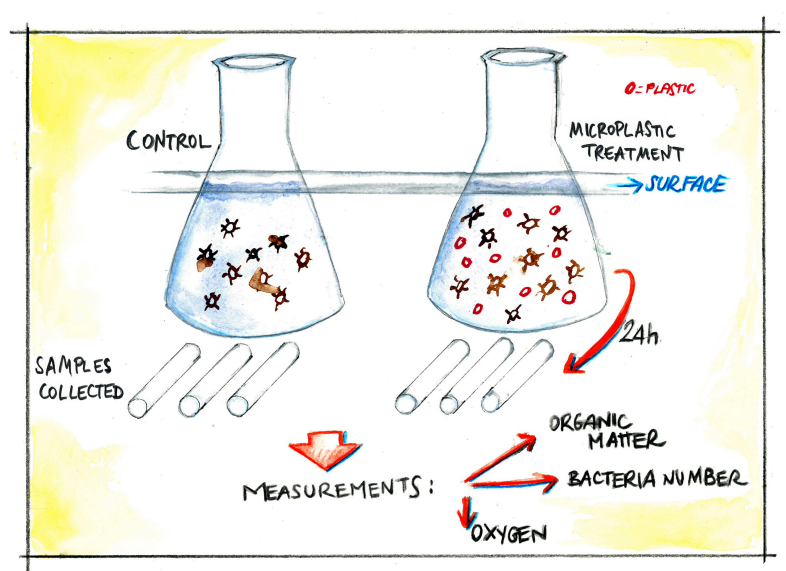

Figure 3

count. These particle-attached bacteria probably helped to lower the oxygen concentration.

Our experiment proved an important concept. When bacteria find microplastics, they produce more organic matter and consume more oxygen. Why do bacteria produce more organic matter when plastic particles are present? Bacteria like to attach to particles. When they find plastic particles, they produce and transform organic matter that help them to stick to the particles.

\section{PLASTICS IN THE OCEAN MAY CONTRIBUTE TO CLIMATE CHANGE}

The presence of microplastics in the sea surface is a serious problem that can interfere with fundamental biological processes. These processes control the flow of important gases, like oxygen, between the sea surface and the atmosphere. Using oxygen, bacteria transform organic matter in the sea water and, in the process, produce $\mathrm{CO}_{2}$. When there is a lot plastic present, bacteria consume more oxygen. This is a problem because less oxygen will be available for other life. The ocean is the Earth's blue lung: if we reduce its capacity to produce oxygen, we will change how this lung works. This is a problem because, when there is a lot of organic matter on the surface of the ocean, the flow of oxygen from the ocean into the atmosphere might slow down. The flow of $\mathrm{CO}_{2}$ from the atmosphere into the ocean might slow down as well. This is an even bigger problem, because our oceans are one of the prime sinks of $\mathrm{CO}_{2}$, meaning that they absorb a lot of the $\mathrm{CO}_{2}$ that humans emit to the atmosphere through fossil fuels combustion and that, in excess, causes the greenhouse effect and global warming. If the ocean takes up less $\mathrm{CO}_{2}$, the Earth could face unimaginable changes in its climate. The amount of plastic in our oceans is gigantic and keeps increasing. Therefore, we need to think hard about the consequences of increasing amounts of plastics 
Figure 4

(A) The box plot shows the concentration of organic matter (measured as the extinction of light passing through the organic matter in a distance of a meter, therefore $\left.\mathrm{m}^{-1}\right)$ in control (blue) and microplastics (MP) treatment (orange). You can see that there was more organic matter in the presence of microplastics, as shown by the higher minimum and maximum values and the median values (the horizontal line inside the box). (B) The concentration of oxygen (units are $\mu \mathrm{mol}$ oxygen per liter of water: $L^{-1}$ ) was measured in samples from control (blue) and MP treatment (orange). Generally, oxygen concentrations in the water below the surface were lower in the presence of microplastics. This is shown by lower minimum and maximum values and lower median values compared to the control.
A Organic matter: water surface

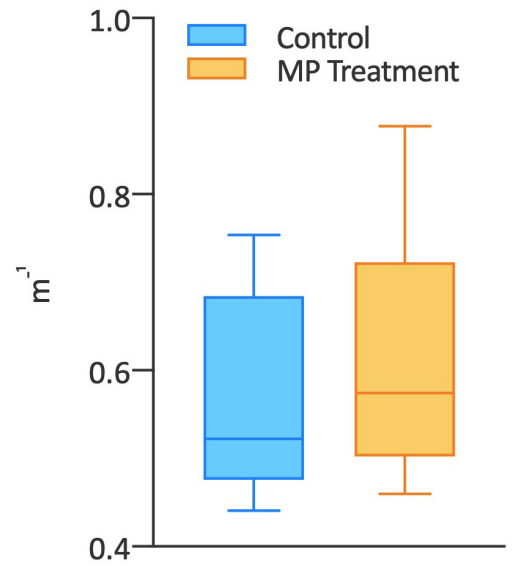

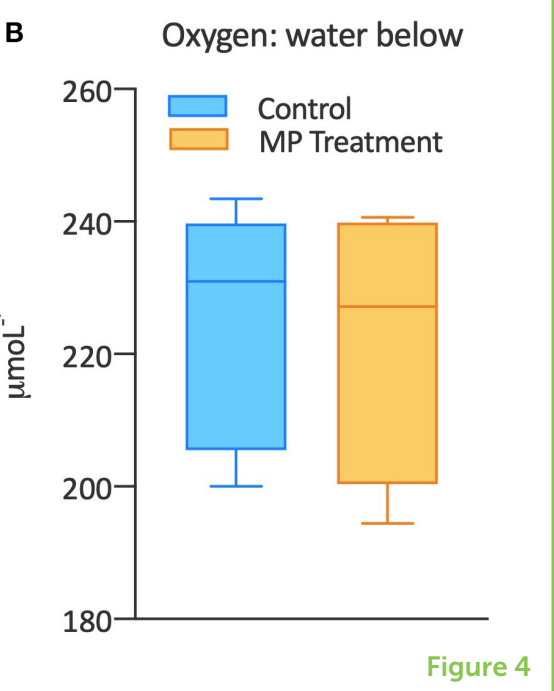

in our rivers and oceans. It is important for all of us to join together with our families, friends, scientists, and society to find solutions to this global problem.

\section{ACKNOWLEDGMENTS}

A huge acknowledgment goes to Teresa Galgani as her artistic contribution in these illustrations was fundamental. The original work was possible thanks to the European Union's Horizon 2020 Research and Innovation Program under the Marie Skłodowska-Curie Grant Agreement No. 702747 POSEIDOMM to LG. We would like to thank Anna, Clara, Stephan, and Karina for their useful insights and suggestions. Their critical sense and curiosity toward the topic remarkably helped the reviewing process.

\section{ORIGINAL SOURCE ARTICLE}

Galgani, L., and Loiselle, S. A. 2019. Plastic accumulation in the sea surface microlayer: an experiment-based perspective for future studies. Geosciences 9:66. doi: 10.3390/geosciences9020066

\section{REFERENCES}

1. MacIntyre, F. 1974. The top millimeter of the ocean. Sci. Am. 230:62-77. doi: 10.1038/scientificamerican0574-62

2. Garabétian, F. 1990. Production de $\mathrm{CO}_{2}$ à l'interface air-mer. Une approche par l'étude des phénomènes respiratoires dans la microcouche de surface $\left[\mathrm{CO}_{2}\right.$ production at the sea-air interface. An approach by the study of respiratory processes in surface microlayer]. Int. Rev. Hydrobiol. 75:219-29. doi: 10.10 02/iroh.19900750208 
3. Carpenter, E. J., and Smith, K. L. 1972. Plastics on the Sargasso sea surface. Science 175:1240-1. doi: 10.1126/science.175.4027.1240

4. Galgani, L., and Loiselle, S. A. 2019. Plastic accumulation in the sea surface microlayer: an experiment-based perspective for future studies. Geosciences 9:66. doi: 10.3390/geosciences9020066

SUBMITTED: 12 November 2019; ACCEPTED: 04 August 2020; PUBLISHED ONLINE: 07 October 2020.

EDITED BY: Jamileh Javidpour, University of Southern Denmark, Denmark

CITATION: Galgani L and Loiselle SA (2020) How Can Plastic on the Sea Surface Affect Our Climate? Front. Young Minds 8:120. doi: 10.3389/frym.2020.00120

CONFLICT OF INTEREST: The authors declare that the research was conducted in the absence of any commercial or financial relationships that could be construed as a potential conflict of interest.

COPYRIGHT @ 2020 Galgani and Loiselle. This is an open-access article distributed under the terms of the Creative Commons Attribution License (CC BY). The use, distribution or reproduction in other forums is permitted, provided the original author(s) and the copyright owner(s) are credited and that the original publication in this journal is cited, in accordance with accepted academic practice. No use, distribution or reproduction is permitted which does not comply with these terms.

\section{YOUNG REVIEWER}

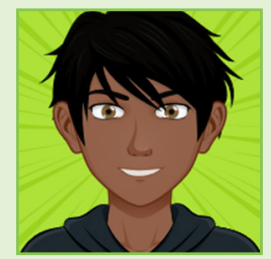

\section{SAMUEL, AGE: 12}

In my free time I like to go out with my friends. We often meet at places where we are able to play football. Besides that I am part of an athletic club. I am attending the training sessions 2-3 times a week. After coming home from school I usually start with my homework to have free time afterwards.

\section{AUTHORS}

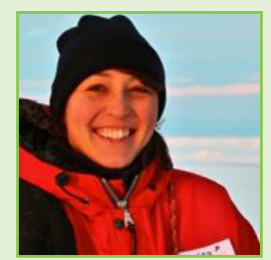

\section{LUISA GALGANI}

Luisa Galgani is an aquatic scientist whose research is mainly focused on human impacts on carbon dynamics in marine and freshwater environments. Among these impacts, she studies the effects of plastics and climate change. She has been working between Italy, Germany, and the US. Her research led her to spend many days navigating, that she loves. She studied different seas, from the Mediterranean to the Arctic, South Pacific, Central Atlantic, and Indian Ocean. She also performs experiments in the lab, but most of all she loves being on board in the middle of the ocean. *luisa.galgani@icloud.com 


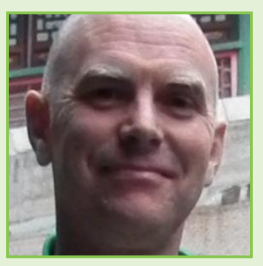

\section{STEVEN A. LOISELLE}

Steven Loiselle is an aquatic scientist whose research has focused on the dynamics of freshwater and marine ecosystems. He and his colleagues have developed new approaches to monitoring and management of aquatic environments for their conservation and reduce the impact of global megatrends like climate change, urbanization, and the increase of intensive agriculture. This has taken him to perform studies on the African Great Lakes, Paraná wetlands, Yangtze valley lakes, and coastal environments in the Mediterranean, where he lives. 